\title{
CRUCIAL APPROACHES TO DIAGNOSTICS AND ANAEMIA TREATMENT IN PREGNANT WOMEN WITH HEART FAILURE AT THE EXTRAGENITAL PATHOLOGY CLINIC
}

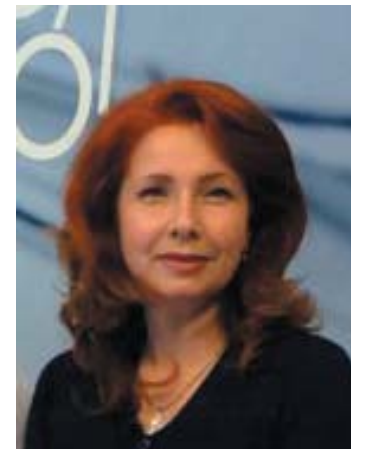

Yu.V. DAVYDOVA

$M D$, Head of the Obstetrical Problems of Extragenital Pathology Department, Institute of Pediatrics, Obstetrics, and Gynecology of NAMS of Ukraine, Kyiv, Ukraine

\section{K.G. APRESOVA}

$M D$, chief researcher, Obstetrical Problems of High Risk Pregnancy

Department, Institute of Pediatrics, Obstetrics, and Gynecology of NAMS of Ukraine, Kyiv, Ukraine

\section{A.A. OGORODNIK}

$\mathrm{PhD}$, junior researcher, Obstetrical Problems of High Risk Pregnancy Department, Institute of Pediatrics, Obstetrics, and Gynecology of NAMS of Ukraine, Kyiv, Ukraine

\section{A.N. MOKRIK}

$\mathrm{PhD}$, researcher, Obstetrical Problems of High Risk Pregnancy Department, Institute of pediatrics, Institute of Pediatrics, Obstetrics, and Gynecology of NAMS of Ukraine, Kyiv, Ukraine

\section{A.Yu. LIMANSKAYA}

$\mathrm{PhD}$, senior scientist, Obstetrical Problems of High Risk Pregnancy Department, Institute of Pediatrics, Obstetrics, and Gynecology of NAMS of Ukraine, Kyiv, Ukraine

\section{L.P. BUTENKO}

Institute of Pediatrics, Obstetrics, and Gynecology of NAMS of Ukraine, Kyiv, Ukraine

\section{A.V. PASHYNNYI}

Institute of Pediatrics, Obstetrics, and Gynecology of NAMS of Ukraine, Kyiv, Ukraine
W ithin the last twenty years a range of problems and their nature, the specialists of the High Risk Pregnancy Department are facing, has significantly increased.

For a number of years the congenital heart diseases and a part of the congenital heart diseases were considered to be a contraindication for getting pregnant and carrying of a pregnancy. Today, a consensus among cardiac surgeons, cardiologists, and obstetrician-gynecologistshas been reached: the most of such patients will have an opportunity to carry the pregnancy and to deliver a baby without health damage subject to adequate assessment of cardiac reserve, peculiarities of haemodynamics, and proper psychological and medical supervision.

In modern perinatology and at thehigh risk pregnancyclinic a great attention is paid to stratification of «cardiac events» risks and perinatal complications. A great contribution to this was made by development and practical use of CarPreg and ZAHARA risk scales; prediction is defined by a score method and includesassessment of a heart disease type, availability and a degree of circulatory inefficiency, a degree of pulmonary hypertension, and hypoxemia intensity. These are the factors that aggravate the prediction, cause pregnancy complications and problems withphysiological fetal development. The main reason in forming obstetric and perinatal complications is due to prolonged hypoxia and heart failure in women with congenial heart diseases (CHD) [6, 7].

Taking into consideration signing of $\mathrm{WHO}$ Resolution on Protecting reproductive rights by our country, it is necessary to ensure the rights ofwomen with severe somatic and neurologic pathology such as the right toobtain adequate information concerning their health state and possible effect of the present pathology on a gestational process and future baby; to have an access to safe, efficient, inexpensive, and affordable birth control methods up to their choice; to have access to relevant public health services ensuring safe pregnancy and labour to every woman, as well as arrangement of the best opportunities for married couples to have a healthy child.

Taking into account the foregoing, the necessity to hospitalize pregnant women with the most severe diseases to the Department of Ob- stetric Problems in High Risk Pregnancy in the Institute of Pediatrics, Obstetrics, and Gynecology of NAMS of Ukraine, is performed in compliance with the regionalization principles toperinatal care in Ukraine, as well as an extension of modern diagnostics and treatment methods, prevention of perinatal complications. Thus we need to work out an approach to each pregnant woman without modern clinical practice guidelines for a number of nosological forms (including the cases of oncology pathology, severe cardiovascular pathology, etc.). It presupposes search of new approaches to solve both common and individual clinical cases.

\section{CARDIOVASCULAR PATHOLOGY AND ANEAMIA}

Aneamia can be a cause of chronic heart failure (CHF) and its result. Today it is considered that pathogenesis of aneamia association with CHF has not been still found out, it can comprise a number of mechanisms: renal dysfunction (reduction of erythrogenesis in cases of aneamia), inflammation (erythropoietin resistence), age, the female sex, decrease in a body mass index, intestinal absorption disorders, long-term administration of aspirin, proteinuria. A special role in the pathogenesisis assigned to proinflammatory cytokines that promote aneamia of chronic disease (ACD) in cases of CHF $[1,4,8]$.

The ACD is the second most frequent type of aneamia after asiderotic anemia (AA). According to different sources this type of anemia is the most frequent among patients with the $\mathrm{CHF}$ and it is observed in cases of over than $50 \%$ patients $[11,12]$. Results of the latest researches proved that the basis of the ACD is an immune-mediated mechanism: imbalance of cytokine and reticuloendothelial system cell interaction causes disorders of iron homeostasis, proliferation of erythropoiesis precursors, erythropoietin production, and life time of erythrocytes $[2,7,8]$. Discovery of hepcidin - an acute-phase iron-regulating protein had a revolutionary significance that proved connection between an immune mechanism of iron metabolism disorders and progress of the $\operatorname{ACD}[3,7,9]$.

Under the influence of inflammatory stimuli (mainly IL6) in the liver enhancement of hepcidin synthesis occurs. It causes reduction in intestinal 
absorption of iron and blocking iron release from macrophages. Disorder of iron metabolism regulation results in further insufficiency of available iron for the erythropoiesis precursors, reduction in proliferation of these cells due to an adverse effect of heme biosynthesis imbalance on them $[2,4,6,8,10]$.

The necessity to manage iron deficiency in pregnant women having cardiovascular diseases is absolutely reasonable, as iron participates in a great number of essential biochemical processes:

oxygen transportation and storage (haemoglobin, myoglobin);

p participation in cell proliferation;

p participation in forming active centers of oxidation-reduction enzymes (oxidase, hydroxylase);

p electron transportation (cytochromes, ironserum proteides);

generation of active forms of oxygen and ATP;

T iron transportation and storage (transferrin, ferritin, hemosiderin, chelating agents).

In addition, in experimental studies iron deficiency promoted progress of diastolic dysfunction of the left ventricle, its hypertropia, dilation, and fibrosis.

According to the foregoing we proved the following examination algorithm for pregnant women with heart diseases of various ethiology and NYHA II-III heart failure.

1. Clinical blood test (reduction in a haemoglobin level below the standard by trimesters treatment of aneamia).

If the heamoglobin level remains within normal limits for a certain trimester but there have been observed signs of apparent heart failure, disorders of life qualities (dyspnea, undue fatiguability, cardiac pains), then the algorithm provides the following examination:

2. C-reactive protein (avoidance of the active phase of the inflammatory process, $\mathrm{mg} / \mathrm{l}$ ).

3. Ferritin $(\mu \mathrm{g} / \mathrm{L})$.

4. Transferrin saturation (TSAT, \%).

5. Brain natriuretic peptide (BNP, pg/ml).

Let's provide a clinic example. A pregnant woman V., 24 years old, gestation period is 34 weeks, dilated cardiomyopathy, NYHA III. The clinical blood test shows the heamoglobin level of $106 \mathrm{~g} / \mathrm{l}, \mathrm{SRP}-5.6 \mathrm{mg} / \mathrm{l}$ (norm), ferritin - 98.6 $\mu \mathrm{g} / \mathrm{L}$, iron $-6.38 \mathrm{mcmol} / \mathrm{l}$ (reduced level), transferring - $4.3 \mathrm{~g} / \mathrm{l}$ (increased level), TSAT - 6\%, BNP - $108 \mathrm{pc} / \mathrm{ml}$. As per recommendations of the European Society of Cardiology related toprenatal care and labour of women having cardiovascular pathology dated 2011 as a labour methodfor this patient it was chosen the Cesarean section due to low ejection fraction (32\%). Taking into account common approaches to prevention and treatment of the asiderotic an- eamia, if in the third trimester the heamoglobin level is over $105 \mathrm{~g} / \mathrm{l}$, then treatment by means of ferruginous preparations is not recommended. At the same time the patient experienced reduction of ferritin level $(<100 \mu \mathrm{g} / \mathrm{L})$ and transferrin saturation $(<20 \%)$, and she has a high level of heart failure biomarker (BNP > $100 \mathrm{pg} / \mathrm{ml}$ ) that requires change in medications and prescription of ferruginous preparations under conditions of the scheduled abdominal labour with expected supra-physiological hemorrhage.

To correct the aneamic state it was chosen an iron polymaltose complex (Maltofer) in a dose of 1 tablet twice per day. A basis for choice of this preparation was its pharmacological advantages over ionic ferruginous preparations: an opportunity to combine administration with other preparations, avoidance of potential oxidative stress aggravation of the woman having heart failure. The therapy was started three weeks before the scheduled delivery and continued during the postoperative period. Within the postoperative period the heamoglobin level made $103 \mathrm{~g} / \mathrm{l}$, TSAT - 25\%, ferritin level - $120 \mu \mathrm{g} / \mathrm{L}$.

Let's provide another clinic example. A pregnant woman L., 20 years old, gestation period is 34 weeks, coarctation of aorta, the heart was operated in 1997, restenosis, NYHA of II degree. Clinical blood test: $\mathrm{Hb}-108 \mathrm{~g} / \mathrm{l}, \mathrm{SRP}-7.3$ $\mathrm{mg} / \mathrm{l}$ (norm), ferritin- $99.1 \mu \mathrm{g} / \mathrm{L}$ (reduced level), iron - $8.91 \mathrm{mcmole} / \mathrm{l}$ (reduced level), transferrin - $4.1 \mathrm{~g} / \mathrm{l}$ (norm), TSAT - 8\% (reduced level), BNP - $118.6 \mathrm{pg} / \mathrm{ml}$ (increased level). Taking into consideration indices of the cardiac reserve as a delivery method it is chosen the Cesarean section. Based on data of the laboratory test, echocardiography parameters, aggravation of heart failure it was decided to carry out premature delivery on the term of 36 weeks. During two weeks before the surgical delivery and two weeks during the postoperative supervision the patient is prescribed Maltofer in a dose of 1 tablet twice per day. The postoperative period was smooth, the heamoglobin level was $102 \mathrm{~g} / \mathrm{l}$, TSAT - 22\%.

Let's provide the third clinical case. A pregnant woman A., 29 years old, gestation period is 22-23 weeks, CHD - Fallot's tetrad, the heart was operated in 1996, NYHA II. Clinical blood test: heamoglobin - $105 \mathrm{~g} / \mathrm{l}, \mathrm{SRP}-4.6 \mathrm{~g} / \mathrm{l}$ (norm), TSAT - 19\% (reduced level), BNP - $94 \mathrm{pg} / \mathrm{ml}$ (norm). Taking into account that there is an indication for reduction of transferrin saturation it is recommended Maltofer therapy in a dose of 1 tablet twice per day with follow-up control of iron metabolism indices. In two weeks after the therapy had been started it was noted reduction of fatiguability, exertional dyspnea, in one month the heamoglobin level was $110 \mathrm{~g} / \mathrm{l}$, TSAT 22\%.

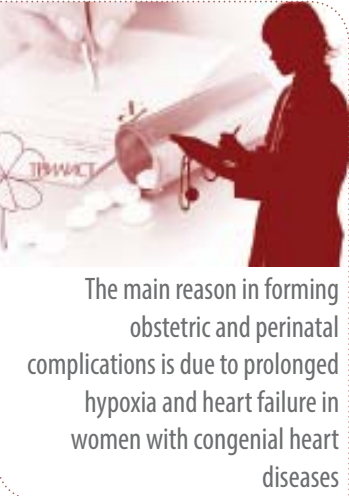

diseases 


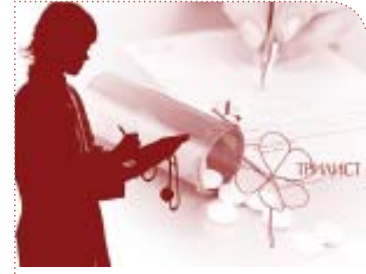

Overlap of aneamia and heart failure can cause a high risk of fetus growth inhibition, prematurity, a low-birth-weight infant
It should be noted that among 48 pregnant women having CHD of "acyanotic type» rate of asiderotic aneamia was $29.6 \%$, their average heamoglobin level was $97.6+3.4 \mathrm{~g} / \mathrm{l}$. In this group the iron polymaltose complex was prescribed within therapeutic dosage for 2-3 months with further recommendations to take a maintenance dose. Neither of the women had complaints of the gastrointestinal tract, there were no cases of rejection of the therapy. An average improvement of heamoglobin indices was noted in $10.2 \pm 3.1$ days, effect duration made $94.2 \pm 4.2$ days.

\section{DISCUSSION}

It is required to note that aneamia is still the least understandble among a variety of comorbide states and complications of the CHF. However, there can be no doubt that this combination of aneamia and heart failure aggravates the prediction, increases a risk of severe «cardiac events», and perinatal complications. Overlap of aneamia and heart failure can cause a high risk of fetus growth inhibition, prematurity, a low-birthweight infant.

In 2009 it was published ameta-analysis of 20 clinical researches $(97,699$ patients) which confirmed an actual level of aneamia availability with a high risk of fatal outcome in cases of HF. Moreover, these patients had worse exercise tolerance (NYHA III-IV) and lower ejection fraction of the left ventricle (LVOT) [3].
It is worth to analyze a review of 34 researches (153,180 patients having CHF). According to it, death rate of patients withaneamiawas $46.8 \%$ compared to $29.5 \%$ of patients who did not suffer from aneamia $(p<0.001)$ irrespective of a type of heart failure [9].

But it should be underlined that the research data mainly referred to groups of patients of elder age. Genesis of their heart failure differed from the one that had young patients. Researches in this sphere are to be continued. They will provide an opportunity to improve life quality and perinatal outcomes significantly in the group of pregnant women having severe cardiovascular pathology.

Today due to a tendency towards unification of medical care and standard orientation, effective recommendations are based on demonstrative researches of a particular time period. They are not able to predict uniqueness of the human organism, individual compensatory and adaptive reactions. Therefore it is required a scientific research, analysis of the «best practices», a translation approach to improvement of diagnostics and medical management, especially in groups of pregnant women having a high risk by maternal and perinatal complications...

\section{REFERENCES/ЛИTЕРАTУРA}

1. Deswal A, Petersen NJ, Feldman AM, Young JB, White BG, Mann DL

Cytokines and cytokine receptors in advanced heart failure: an analysis of the cytokine database from the Vesnarinone trial (VEST). // Circulation. 2001; 103: 2055-2059.

2. Ezekowitz JA, McAlister FA, Armstrong PW

Anemia is common in heart failure and is associated with poor outcomes: insights from a cohort of 12065 patients with new-onset heart failure. // Circulation. 2003; 107: 223-225.

3. He SW, Wang LX

The impact of anemia on the prognosis of chronic heart failure: a meta-analysis and systemic review. // Congest Heart Fail 2009; 15: 123.

4. Ganzevoort W

Plasma volume and blood pressure regulation in hypertensive pregnancy //

J. Hypertens. - 2004. - Vol. 22. - P. 1235-1242.

5. Gei AF

Cardiac disease and pregnancy/ A.F. Gei, G.D.Hankins // Obstet. Gynecol. Clin.North.

Am. - 2001. - Vol. 28. - P. 465 - 512.

6. Gelson E

Cardiac disease in pregnancy: congenital heart disease/ E. Gelson, M. Jhonson,

M. Gatzolius et al. // The Obst. and Gynaec. 2007. N 9. P. 15-20.

\section{Globits S}

Atrial natriuretic peptide release is more dependent on atrial filling volume than on filling pressure in chronic congestive heart failure/ S. Globits, H. Frank, B. Pacher et al. // Am. Heart J. - 1998. - N 135. - P. 592-597.

8. Silverberg DS, Wexler D, Palazzuoli A et al.

The anemia of heart failure. // ActaHaematol 2009; 122: 109.

9. Shah R, Agarwal AK

Anemia associated with chronic heart failure: current concepts. // ClinInterv Aging 2013; 8: 111 .

10. Szachniewicz J, Petruk-Kowalczyk J, Majda J, Kaczmarek A, Reczuch K, Kalra PR, Piepoli MF,

Anker SD, Banasiak W, Ponikowski P

Anaemia is an independent predictor of poor outcome in patients with chronic heart failure. Int J Cardiol. 2003; 90: 303-308.

11. Tanner H, Moschovitis G, Kuster GM, Hullin R, Pfiiffner D, Hess OM, Mohacsi P

The prevalence of anemia in chronic heart failure. // Int J Cardiol.2002; 86: 115-121. 12. Tang Yi-Da, Katz S

Anemia in chronic heart failure. Prevalence, Etiology, Clinical correlates and Treatment options. // Circulation. 2006; 113: 2454-2461. 


\section{CRUCIAL APPROACHES TO DIAGNOSTICS AND ANAEMIA TREATMENT IN PREGNANT WOMEN WITH HEART FAILURE AT THE HIGH RISK PREGNANCY CLINIC}

Yu.V. Davydova, MD, Head of the Obstetrical Problems of Extragenital Pathology Department, Institute of Pediatrics, Obstetrics, and Gynecology of NAMS of Ukraine, Kyiv, Ukraine

K.G. Apresova, MD, chief researcher, Obstetrical Problems of Extragenital Pathology Department, Institute of Pediatrics, Obstetrics, and Gynecology of NAMS of Ukraine, Kyiv, Ukraine

A.A. Ogorodnik, PhD, junior researcher, Obstetrical Problems of Extragenital Pathology Department, Institute of Pediatrics, Obstetrics, and Gynecology of NAMS of Ukraine, Kyiv, Ukraine

A.N. Mokrik, PhD, researcher, Obstetrical Problems of Extragenital Pathology Department, Institute of Pediatrics, Obstetrics, and Gynecology of NAMS of Ukraine, Kyiv, Ukraine

A.Yu. Limanskaya, PhD, senior scientist, Obstetrical Problems of Extragenital Pathology Department, Institute of Pediatrics, Obstetrics, and Gynecology of NAMS of Ukraine, Kyiv, Ukraine

L.P. Butenko, Institute of Pediatrics, Obstetrics, and Gynecology of NAMS of Ukraine, Kyiv, Ukraine

A.V. Pashynnyi, Institute of Pediatrics, Obstetrics, and Gynecology of NAMS of Ukraine, Kyiv, Ukraine

According to modern concepts, aneamia can be a cause of chronic heart failure (CHF) and its result. According to different sources aneamia of chronic disease is the most frequent among patients with the CHF and it is observed in cases of over than $50 \%$ patients.

There can be no doubt that combination of aneamia and heart failurein pregnant aggravates the outcomes, increases a risk of severe «cardiac events», and perinatal complications. Overlap of aneamia and heart failure can cause a high risk of fetus growth inhibition, prematurity, a low-birth-weight infant.

According to the foregoing we proved the following examination algorithm for pregnant women with congenital heart diseases of various ethiology and NYHA II-III heart failure.

1. Clinical blood test (reduction in a haemoglobin level below the standard by trimesters - treatment of aneamia). If the heamoglobin level remains within normal limits for a certain trimester but there have been observed signs of apparent heart failure, disorders of life qualities (dyspnea, undue fatiguability, cardiac pains), then the algorithm provides the following examination:

2. C-reactive protein (avoidance of the active phase of the inflammatory process).

3. Ferritin.

4. Transferrin saturation.

5. Brain natriuretic peptide.

Keywords: aneamia, pregnancy, heart failure, diagnostics, treatment, Maltofer.

\section{КЛЮЧЕВЫЕ ПОДХОДЫ К ДИАГНОСТИКЕ И ЛЕЧЕНИЮ АНЕМИИ У БЕРЕМЕННЫХ С СЕРДЕЧНОЙ НЕДОСТАТОЧНОСТЬЮ В КЛИНИКЕ ЭКСТРАГЕНИТАЛЬНОЙ ПАТОЛОГИИ}

Ю.В. Давыдова, д. мед. н., зав. отделением акушерских проблем экстрагенитальной патологии Института педиатрии, акушерства и гинекологии НАМН Украины

К.Г. Апресова, д. мед. н., главный научный сотрудник отделения акушерских проблем экстрагенитальной патологии Института педиатрии, акушерства и гинекологии НАМН Украины

А.А. Огородник, младший научный сотрудник отделения акушерских проблем экстрагенитальной патологии Института педиатрии, акушерства и гинекологии НАМН Украины

А.Н. Мокрик, к. мед. Н., научный сотрудник отделения акушерских проблем экстрагенитальной патологии Института педиатрии, акушерства и гинекологии НАМН Украины

А.Ю. Лиманская, к. мед. н., старший научный сотрудник отделения акушерских проблем экстрагенитальной патологии Института педиатрии, акушерства и гинекологии НАМН Украины

Л.П. Бутенко, Институт педиатрии, акушерства и гинекологии НАМН Украины

А.В. Пашинный, Институт педиатрии, акушерства и гинекологии НАМН Украины

Согласно современным представлениям, анемия может быть причиной хронической сердечной недостаточности (ХСН) и ее результатом. По разным источникам, анемия при хроническом заболевании является наиболее частой среди пациентов с ХСН и наблюдается более чем у $50 \%$ больных. Нет никаких сомнений, что сочетание анемии и сердечной недостаточности у беременных усугубляет прогноз, увеличивает риск развития тяжелых «сердечных событий» и перинатальных осложнений. Сочетание анемии и сердечной недостаточности может стать причиной задержки роста плода, недоношенности, низкого веса при рождении ребенка.

Мы предлагаем следующий алгоритм обследования беременных женщин с заболеваниями сердца различной этиологии и сердечной недостаточностью II-III ст. по классификации NYHA.

1. Клинический анализ крови (снижение уровня гемоглобина ниже нормы в триместрах - следует проводить лечение анемии). Если уровень гемоглобина в пределах нормы в течение определенного триместра, но наблюдаются признаки явной сердечной недостаточности, нарушения жизненных функций (одышка, повышенная утомляемость, боли в сердце), то следует определить уровень следующих показателей:

2. С-реактивный белок (для исключения активной фазы воспалительного процесса).

3. Ферритин.

4. Насыщение трансферрином.

5. Мозговой натрийуретический пептид.

Ключевые слова: анемия, беременность, сердечная недостаточность, диагностика, лечение, Мальтофер. 